\title{
Copepods act as omnivores in a (sub)tropical reservoir: Implication for the top-down effect on phytoplankton
}

\author{
Qiuqi LIN, ${ }^{*}$ Liang PENG, Yang YANG, Bo-Ping HAN* \\ Institute of Hydrobiology, Jinan University, Guangzhou 510632, China \\ *Corresponding authors: tlinqq@jnu.edu.cn; tbphan@jnu.edu.cn
}

\begin{abstract}
Tropical reservoirs in China receive a high input of organic matter from surrounding watersheds and this represents a significant resource for zooplankton consumers. Copepods are often the dominant zooplankton group in the tropical systems. Whether copepods tend to be omnivorous and their potential cascading effect on phytoplankton are subjects of debate. We used stable carbon and nitrogen isotope analyses to elucidate the allochthony and trophic positions of two copepod species (Phyllodiaptomus tunguidus and Mesocyclops thermocyclopoides) and one cladoceran species (Diaphanosoma orghidani) over a one-year period in a tropical oligo-mesotrophic reservoir in China. We assumed the filter-feeding $D$. orghidani was herbivorous and we used it as a baseline indicator of $\delta^{15} \mathrm{~N}$ to estimate the trophic position of the two copepods. P. tunguidus and M. thermocyclopoides had an average trophic level that was 0.7 and 0.5 higher, respectively, than that of $D$. orghidani. $M$. thermocyclopoides showed seasonal differences in trophic position and an increase in trophic position with rising temperatures, whereas $P$. tunguidus remained omnivorous throughout the year. All three zooplankton species had a much higher degree of allochthony in the flood season than in the dry season, and their allochthony was positively related to the allochthony of the particulate organic matter input. The two copepods' omnivorous behavior suggests their allochthony was primarily linked to microbial food web based on the input of terrestrial organic matter. The chlorophyll a to total phosphorus ratio was much higher when P. tunguidus dominated the zooplankton community than when $D$. orghidani dominated. The ratio was positively related to the ratio of omnivorous adult copepods to cladoceran biomass but not to the zooplankton:phytoplankton biomass ratio. Our results suggest that copepods tended to be omnivorous and relied heavily on allochthonous material in the study reservoir. The indirect cascading effect is likely to be stronger than the direct grazing effect, resulting in a positive effect of copepods on the phytoplankton.
\end{abstract}

Key words: Cascading effect; copepods; omnivory; allochthony; phytoplankton.

Received: December 2017. Accepted: April 2018.

\section{INTRODUCTION}

The association between chlorophyll a and total phosphorus (TP) is a fundamental limnological relationship that reflects multiple aspects of ecosystem function (Filstrup et al., 2014). Phosphorus availability in lakes often determines the potential phytoplankton biomass, the amount of which may be determined by physical, chemical, and biological characteristics of the water body, but particularly fish predation and associated grazer communities (Vanni and Findlay, 1990; Mazumder, 1994; Spears et al., 2013; Lin et al., 2014). A significant decline in the ratio of chlorophyll a to TP of grazers (top-down control) has been documented in previous comparative lake studies or in mesocosm experiments with and without large-bodied zooplankton (Sarnelle, 1992; Mazumder, 1994). These studies showed that grazers could suppress chlorophyll a well below their potential based on phosphorus availability and could introduce considerable variance into the ratio between chlorophyll a and TP.
Cladocerans and copepods are the two major groups of mesozooplankton in lakes. Herbivorous cladocerans are microphageous filter feeders that feed primarily on picophytoplankton and nanophytoplankton, while copepods are macrophageous consumers that tend to feed on larger food particles (Sommer and Sommer, 2006). Mesocosm experiments have indicated that herbivore control of phytoplankton biomass could depend on the functional diversity of herbivores, and that the combined impact of microphageous and macrophageous herbivores can cause a decline in total phytoplankton biomass (Sommer et al., 2001). However, in contrast to filter feeders, copepods actively select and catch their food particles (DeMott, 1988). Analyses of copepod gut contents, feeding appendages, and feeding experiments revealed that some copepods feed on both phytoplankton and animal food and are therefore omnivores (Conley and Turner, 1985). Stable isotope analyses showed that omnivory is indeed very common in copepods, and calanoids as well as cyclopoids may have a higher trophic level than filter feeders (Feuchtmayr et al., 2004). The 
effect of copepods on phytoplankton is believed to occur via three food chains: copepods $\rightarrow$ large phytoplankton, copepods $\rightarrow$ large protozoans $\rightarrow$ nanophytoplankton, and copepods $\rightarrow$ heterotrophic nanoflagellates $\rightarrow$ picophytoplankton (Sommer and Sommer, 2006). Mesocosm experiments showed that marine copepods negatively affect large phytoplankton via the first chain and a positive effect on small phytoplankton via the second chain, but a neutral effect when copepods act as omnivores (Stibor et al., 2004). Copepods are the dominant mesozooplankton in tropical reservoirs in China, where bighead carp and silver carp are extensively used for fish production. The chlorophyll a to TP ratio is higher in these copepod-dominated systems than typically observed in temperate cladoceran-dominated lakes, suggesting that copepods may have either a neutral or a positive effect on phytoplankton biomass in these reservoirs (Lin et al., 2014).

Unlike marine pelagic systems, inland waters generally receive large amounts of organic matter from the surrounding terrestrial landscape; consequently freshwater crustaceans show different degrees of allochthony (Carpenter et al., 2005; Cole et al., 2011; Francis et al., 2011; Karlsson et al., 2012; Berggren et al., 2014; Wilkinson et al., 2014). The relative importance of allochthony in lakes likely related to factors such as lake color, trophic status, size, ratio of basin area to water surface area, and hydrologic residence time (Jones et al., 1998; Karlsson et al., 2003; Cole et al., 2011; Zigah et al., 2012; Kelly et al., 2014). Reservoirs generally receive more terrestrial organic matter than lakes because they have larger drainage basins and greater inflows (Thornton, 1990). Therefore, allochthonous organic loadings may present an important carbon source to reservoirs. For example, allochthonous organic contributions in Kuybyshev and Rybinsk Reservoirs in Russia are about three times greater than autochthonous contributions regardless of the level of production of organic matter in the reservoirs (Ivatin, 1974). Terrestrial organic matter is available to copepods primarily by a microbial link consisting of bacteria and protozoa. High allochthonous organic matter loading often generates remarkable microbial activities in the riverine and transitional zones of reservoirs, demonstrating an important transfer of organic C to higher trophic levels (Šimek et al., 2001; Comerma et al., 2003). It is therefore likely that copepod allochthony is high in reservoirs. This may potentially have a positive effect on phytoplankton. Terrestrial particulate organic phosphorus is generally unavailable to phytoplankton but can be incorporated into the microzooplankton biomass (ciliates and rotifers) using the microbial loop. Copepods probably favor phytoplankton by recycling particulate organic phosphorus by feeding on microzooplankton. Furthermore, the grazing pressure of copepods and of microzooplankton on phytoplankton would decline if copepods hold a preference for microzooplankton.

Tropical China experiences high rainfall of up to 1800 $\mathrm{mm}$ annually. Precipitation is especially abundant from April to October (flood season), which contributes $75 \%$ of the annual total. Induced overland flows from heavy precipitation can carry large amounts of particulate material from the surrounding drainage basin into the reservoirs (Chen and Jia, 2009; Wang et al., 2011; Ning et al., 2012). A change in terrestrial particulate organic matter (POM) input is likely to introduce a seasonal component to the degree of copepod allochthony and omnivory, and subsequently a considerable variation in the chlorophyll a to TP ratio. To gain a better insight into the effect of copepods on phytoplankton in China's tropical reservoirs, we analyzed the seasonal variation in zooplankton community structure, chlorophyll a, and the stable isotope ratios of calanoids, cyclopoids and POM in a large tropical reservoir, the Liuxihe Reservoir. We hypothesized that the degree of copepod allochthony and omnivory would both be much higher in the flood season than in the dry season in the reservoir, and that the dominance of omnivorous copepods would produce a higher chlorophyll a to TP ratio in the flood season.

\section{METHODS}

Liuxihe Reservoir is a canyon-shaped, oligomesotrophic reservoir located in the subtropical-tropical transition zone of South China $\left(23^{\circ} 45^{\prime} 50^{\prime \prime} \mathrm{N}, 113^{\circ} 46^{\prime} 52^{\prime \prime}\right.$ E), a detailed description of which can be found in Lin et al. (2012) and Wang et al. (2012). The reservoir has an average depth of $21.3 \mathrm{~m}$ and is primarily fed by Lutian and Yuxi rivers. Upstream and surrounding landscape of the reservoir consist primarily of hills covered with approximately $80 \%$ forest. The main water body near the dam is part of the Liuxihe national forest park reserved for recreational use. The warm monomictic reservoir experiences a very short complete mixing period of about two weeks in winter (Wang et al., 2011). Approximately $80 \%$ of precipitation is concentrated during the flood season from April to September. The community of filterfeeding cladocerans is dominated by Diaphanosoma orghidani, and Daphnia galeata occurs in low abundance $\left(<0.5\right.$ ind. $\left.\mathrm{L}^{-1}\right)$ in the early flood season and completely disappears in summer (Lin et al., 2012). Five copepod species are present, dominated by Phyllodiaptomus tunguidus and Mesocyclops thermocyclopoides. Adult copepods are more abundant than cladocerans except in the early flood season (Lin et al., 2006).

Zooplankton, total phosphorus (TP) and chlorophyll a were sampled at least monthly from April 2012 to March 2013 in the central zone of the reservoir (ca. $25 \mathrm{~m}$ depth, 
Wang et al., 2012) and every 6-7 days in the early flood season (April-May, period with a relatively high terrestrial POM load to the lacustrine zone) and early dry season (October-November, period with low terrestrial POM load to the lacustrine zone). Integrated water samples were collected with a 5 -L plexiglass deep-water sampler $(0.5 \mathrm{~m}$ long and $0.12 \mathrm{~m}$ in diameter) from the surface to the bottom at $1-\mathrm{m}$ intervals. The samples were filtered through a 38$\mu \mathrm{m}$ mesh, and zooplankton was preserved in $4 \%$ buffered formalin. Zooplankton was identified into species, counted, and measured under a microscope with an ocular micrometer (Koste, 1978; Shen and Song, 1979; Korovchinsky, 1992; Ueda and Reid, 2003). Crustacean biomass was estimated from length-weight relationships based on length measurements of 40 individuals of each species. Integrated water samples were taken at depths of $0.5,5,10,15$, and $20 \mathrm{~m}$ and analyzed for chlorophyll a and TP. The concentration of TP was determined as molybdatereactive phosphorus following persulfate digestion (Murphy and Riley, 1962). Chlorophyll a was determined spectrophotometrically after acetone extraction (Lin et al., 2005). Chlorophyll a in the $<30 \mu \mathrm{m}$ size fraction was collected by prefiltering the integrated water samples through a $30-\mu \mathrm{m}$-mesh screen before filtering through 0.45 $\mu \mathrm{m}$ membrane filters. The $>30 \mu \mathrm{m}$ size fraction was calculated by subtracting the $<30 \mu \mathrm{m}$ chlorophyll a from the total chlorophyll a. We multiplied chlorophyll a by 67 (Jeppesen et al., 1997) to convert it to phytoplankton dry mass. Temperature was measured at 1-m deep intervals using a Yellow Spring Instrument, and Secchi disk depth was determined each time. Information on inflow was obtained from the Liuxihe hydropower station.

Three samples each for POM, cladoceran $(D$. orghidani), adult calanoid ( $P$. tunguidus) and adult cyclopoid ( $M$. thermocyclopoides) were collected on a monthly basis from the same sites for stable isotope analysis. Crustaceans were collected with a $125-\mu \mathrm{m}$ plankton net in vertical tows through the entire water column. Two hundred adult $P$. tunguidus, 300 adult $M$. thermocyclopoides and 400 D. orghidani were selected from each sample for analysis after $24 \mathrm{~h}$ gut evacuation in filtered reservoir water. Water samples taken $0.5 \mathrm{~m}$ below the surface were filtered through precombusted $\left(500^{\circ} \mathrm{C}\right.$ for $\left.4 \mathrm{~h}\right)$ Whatman $\mathrm{GF} / \mathrm{F}$ filters. To enable measurement of $\delta^{13} \mathrm{C}$ of $\mathrm{POM}$, inorganic $\mathrm{C}$ was removed from $\mathrm{POM}$ following the $\mathrm{HCl}$-fumigation method (Harris et al., 2001). POM and crustaceans were dried at $60^{\circ} \mathrm{C}$ for $48 \mathrm{~h}$ in an oven, transferred to tin capsules, and analyzed for stable isotope ratios using a FlashEA1112 Elemental Analyzer coupled with a Thermo DeltaPlus Advantage Series Mass Spectrometer at the Nanjing Institute of Geography and Limnology. Isotope ratios $\left({ }^{13} \mathrm{C} /{ }^{12} \mathrm{C}\right.$ and $\left.{ }^{15} \mathrm{~N} /{ }^{14} \mathrm{~N}\right)$ are expressed relative to the Vienna PeeDee Belemnite standard (V-PDB) for $\delta^{13} \mathrm{C}$ and atmospheric $\mathrm{N}_{2}$ for $\delta^{15} \mathrm{~N}$. The average analytical error was typically $0.1 \%$ for $\delta^{13} \mathrm{C}$ and $0.2 \%$ for $\delta^{15} \mathrm{~N}$.

The trophic position of filter feeders is roughly a function of the relative biomass of phytoplankton and protozoa within the size limits of edibility. Filter-feeding cladocerans are short-lived organisms, and do not have the same temporal integration of food source isotope signatures as mussels. However, a study by Matthews and Mazumder (2003) shows that the filter-feeding cladoceran Daphnia is better suited for finer scale temporal integration of pelagic $\delta^{15} \mathrm{~N}$ signature. A time series of the $\delta^{15} \mathrm{~N}$ of filter-feeding cladocerans with a carefully chosen temporal resolution may be useful to detect, for example, seasonal patterns of anthropogenic activities in reservoirs. We therefore used common filter-feeding $D$. orghidani in Liuxihe Reservoir as a baseline and assume its trophic position to be 2 . The trophic position of adult copepods was calculated using the formula in Post (2002):

$$
\text { Trophic position }=\left[\left(\delta^{15} \mathrm{~N}_{\text {copepods }}-\delta^{15} \mathrm{~N}_{\text {Diaphanosoma }}\right) / 3.4\right]+2
$$

where 3.4 is the assumed per trophic level increase in $\delta^{15} \mathrm{~N}$.

A stable isotope mixing model employing the simmr package (Parnell and Inger, 2016) was used to assess the allochthony of POM and zooplankton in R based on the $\delta^{13} \mathrm{C}$ samples, the terrestrial source and the phytoplankton source, and on $\delta^{13} \mathrm{C}$ enrichment. Values of $\delta^{13} \mathrm{C}$ for terrestrial organic matter and phytoplankton were obtained from Ning (2013). Enrichment of $\delta^{13} \mathrm{C}$ for POM was set to $0 \pm 0 \%$. For organism samples, $\delta^{13} \mathrm{C}$ enrichment was calculated based on an assumed per-trophic-level carbon isotope fractionation of $0.5 \pm 1.3 \%$ (McCutchan et al., 2003) multiplied by the number of trophic levels between source and consumer levels. The model was run using the simmr_mcmc command with default parameters (iterations $=10000$, burn-in $=1000$, thinning $=10$, number of MCMC chains $=4$ ). Simmr's built-in diagnostic for convergence was used and we found no apparent need for longer Monte Carlo Markov chain analyses.

We used step-wise multiple regression to identify the possible effect of TP, temperature, chlorophyll a, Secchi disk depth, and the omnivorous adult copepod:cladoceran biomass ratio on dependent variables zooplankton biomass, zooplankton trophic position, the chlorophyll a:TP ratio, and the zooplankton:phytoplankton biomass ratio. First, regression analyses were performed with only the main effects and subsequently with both the main effects and their first-order interactions to assess whether interactions improved model fit. Significance levels for independent variables to enter in the models were set to $\mathrm{P} \leq 0.05$. We then partitioned variability in the dependent variables among the selected independent variables by using the varpart function in $\mathrm{R}$ with vegan. All statistical 
analyses were performed in R 3.2.2 (R Development Core Team, 2015) using the packages Vegan (Oksanen et al., 2017) and Arm (Gelman et al., 2016).

\section{RESULTS}

Inflow varied from 3 to $200 \mathrm{~m}^{3} \mathrm{~s}^{-1}$ and was significantly higher in the flood season (April-September 2012: $32.5 \pm 24.5 \mathrm{~m}^{3} \mathrm{~s}^{-1}$ ) than in the dry season (October 2012-March 2013: $11.5 \pm 10.3 \quad \mathrm{~m}^{3} \quad \mathrm{~s}^{-1}$ ) (ANOVA, $\left.F_{1,363}=121, \mathrm{P}<0.001\right)$ (Fig. 1A). Overland flows induced by intensive rainfall carried large amounts of particulate material from the surrounding drainage basin to the reservoir. In the early flood season (April-May), as the warming of lacustrine water lagged behind that of river water, turbid water flowed into the epilimnion. Secchi disk depth consequently decreased from $3 \mathrm{~m}$ in March to $1 \mathrm{~m}$ in early May (Fig. 1C) and depth-integrated TP increased from $13 \mu \mathrm{g} \mathrm{L}^{-1}$ in March to $47 \mu \mathrm{g} \mathrm{L}^{-1}$ in mid May (Fig. 1D). With intensified thermal stratification, inflow water plunged into the metalimnion, and Secchi disk depth increased while TP decreased. During the period of July 2012 to March 2013, Secchi disk depth fluctuated between 3 and $4 \mathrm{~m}$ (Fig. 1C), and TP was stable at around $12 \mu \mathrm{g} \mathrm{L}^{-1}$ (Fig. 1D). Depth-integrated
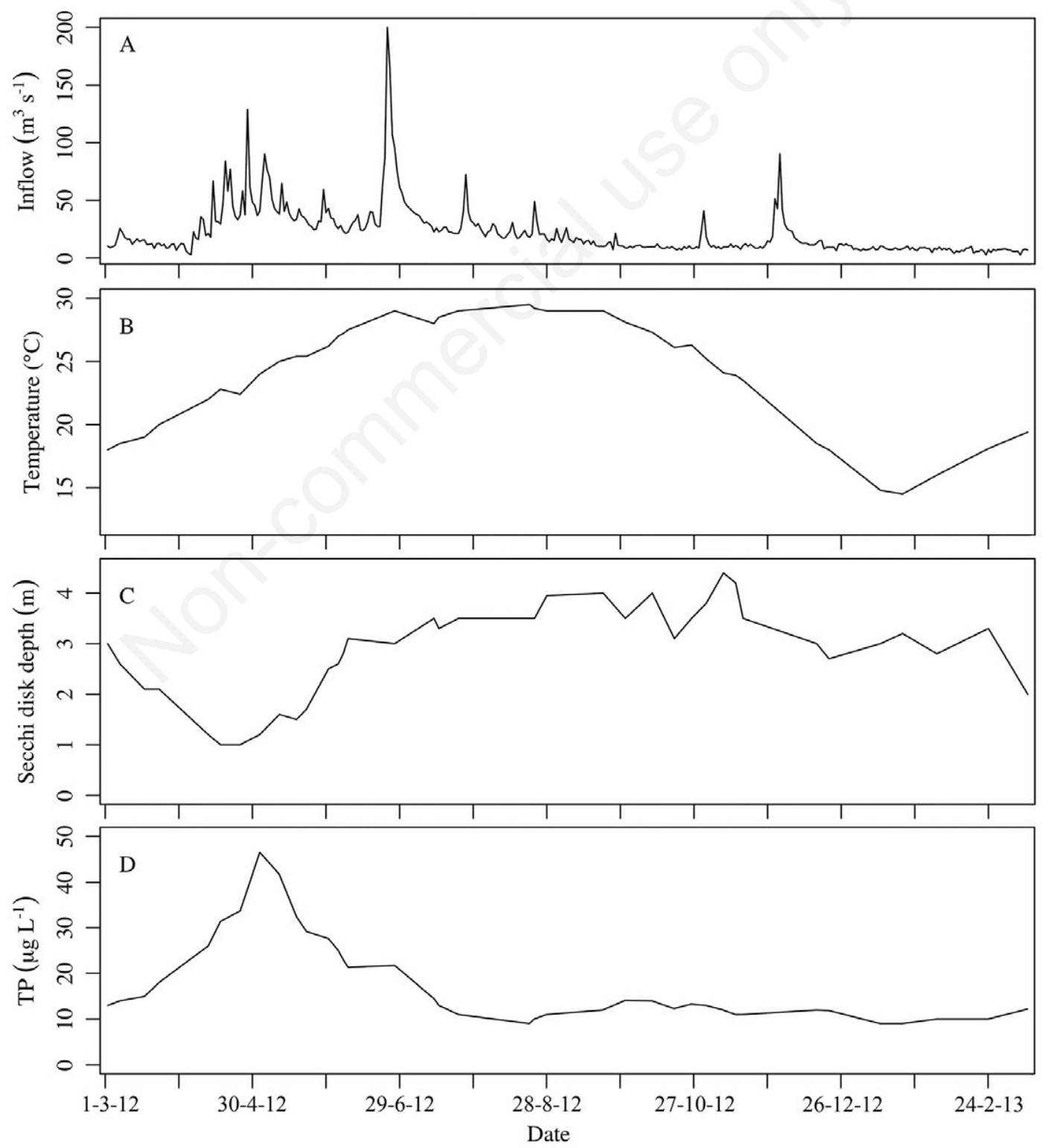

Fig. 1. Temporal variation in (A) inflow, (B) surface temperature, (C) Secchi disk depth and (D) TP. 
chlorophyll a varied from 2.2 to $6.1 \mu \mathrm{g} \mathrm{L} \mathrm{L}^{-1}$, and most of the time phytoplankton $<30 \mu \mathrm{m}$ contributed more than $90 \%$ (Fig. 2A). Diatoms and dinoflagellates dominated the phytoplankton community throughout the year, with dinoflagellates contributing much more in the period between late dry season to early flood season than at other times of the year (Fig. 2B). Phytoplankton $<30 \mu \mathrm{m}$ was primarily composed of Cyclotella spp. and Peridiniopsis elpatiewskyi, while phytoplankton $>30 \mu \mathrm{m}$ constituted Peridinium spp. and Ceratium hirundinella. Chlorophyll a was relatively higher in the early flood season. It was positively related to TP $\left(F_{1,20}=9.893, \mathrm{P}=0.005\right)$ but not to Secchi disk depth $\left(F_{1,20}=2.226, \mathrm{P}=0.151\right)$ and temperature $\left(F_{1,20}=3.924, \mathrm{P}=0.062\right)$.

Zooplankton biomass ranged from 83 to $690 \mu \mathrm{g} \mathrm{L} \mathrm{L}^{-1}$ and exhibited a bimodal pattern of seasonal biomass with a major peak in the early flood season and a minor one in the early dry season (Fig. 2C). Zooplankton biomass was positively related to TP (Fig. 3A) and chlorophyll a
(Fig. 3B), but not to temperature (Fig. 3C). However, multiple regression analysis revealed that zooplankton biomass was positively related to TP but not to chlorophyll a (Tab. 1). Cladocerans contributed 10-73\% of total zooplankton biomass and were dominant in the early flood season (Fig. 2C). The contribution of cladocerans to total zooplankton biomass was significantly higher in the flood season $(46.5 \pm 16.8 \%)$ than in the dry season $(29.4 \pm 12.8 \%$ ) (ANOVA, $F_{1,20}=7.02, \mathrm{P}=0.015$ ). Copepods contributed $25-75 \%$ to the total zooplankton biomass and dominated in other times of the year (Fig. 2C). The percentage of copepods to total zooplankton biomass was significantly higher in the dry season $(56.5 \pm 11.7 \%)$ than in the flood season $\left(42.9 \pm 12.4 \%\right.$ ) (ANOVA, $\mathrm{F}_{1,20}=6.87, \mathrm{P}=0.016$ ). Rotifers only constituted $1-27 \%$ of total zooplankton biomass and showed no significant difference between flood and dry seasons (Fig. 2C). The cladoceran community was primarily composed of D. orghidani, Bosmina fatalis and

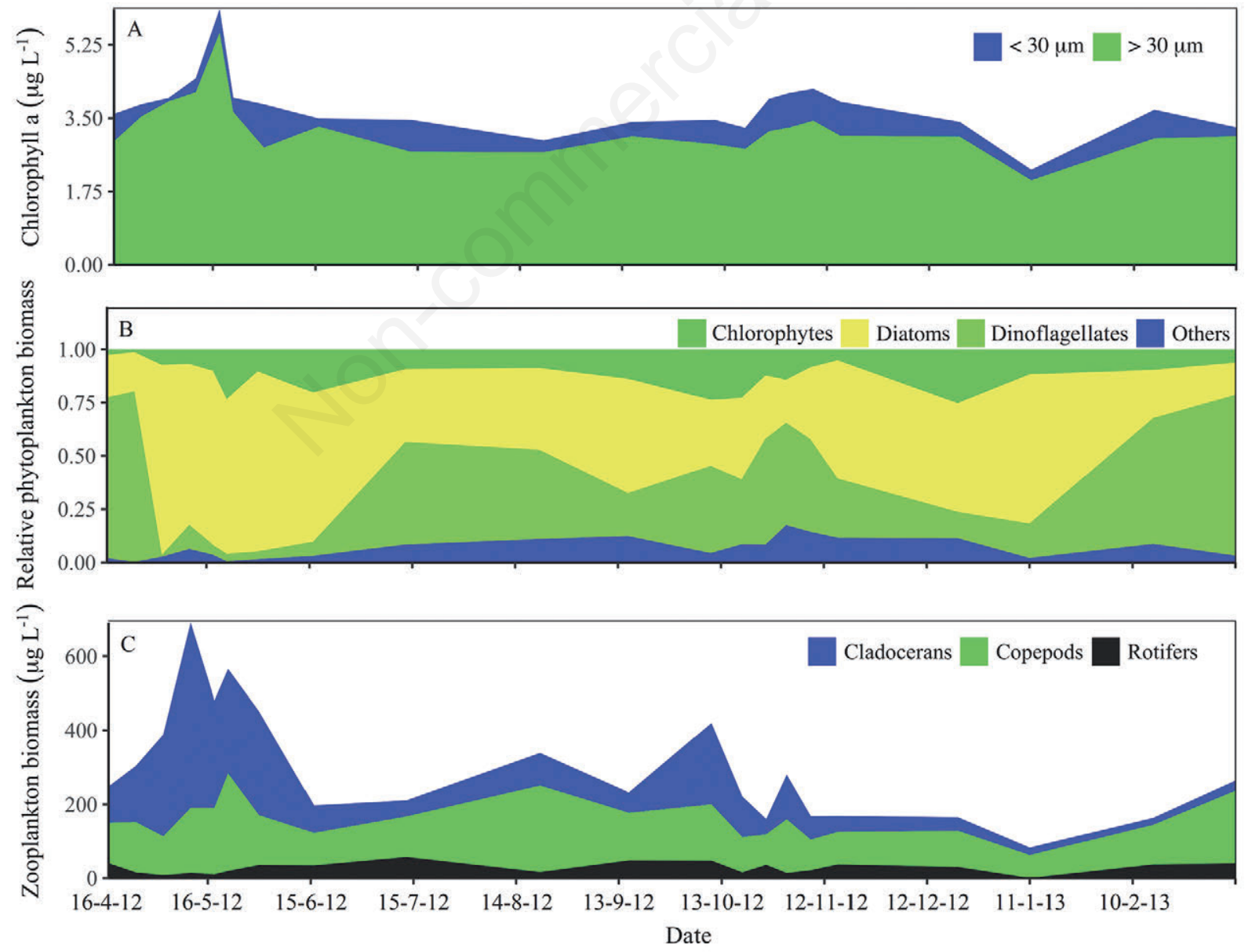

Fig. 2. Seasonal variation in (A) chlorophyll a, (B) phytoplankton community structure and (C) zooplankton biomass. 
Bosminopsis deitersi, while the copepod community included P. tunguidus, M. thermocyclopoides, and Tropocyclops bopingi. D. orghidani dominated in the early flood season, while P. tunguidus dominated in the rest of the year.

There was a seasonal shift in $\delta^{13} \mathrm{C}$ of bulk POM, being more ${ }^{13} \mathrm{C}$-enriched $\left(\delta^{13} \mathrm{C},-26.4 \pm 1.4 \%\right.$ o $)$ during the flood season than POM $\left(\delta^{13} \mathrm{C},-30.0 \pm 0.2 \%\right)$ in the dry season (ANOVA, $\mathrm{F}_{1,10}=39.7, \mathrm{P}<0.001$ ) (Fig. 4). The two copepods $P$. tunguidus and $M$. thermocyclopoides, showed enrichment by $0.1-3.1 \%$ in ${ }^{13} \mathrm{C}$ relative to $\mathrm{POM}$ in the flood season, but a depletion by $1.1-10.0 \%$ in the dry season (Fig.
4). However, the $\delta^{13} \mathrm{C}$ value of the cladoceran D. orghidani was lower than the $\delta^{13} \mathrm{C}$ value of POM in both seasons, and the depletion was smaller in the flood season $(0-2.5 \%)$ than in the dry season (2.7-6.3\%) (Fig. 4). Based on the mixing model results, the median (and 5\% and 95\% confidence intervals) estimated allochthony values of bulk POM varied from $0.61(0.48-0.74)$ to $0.86(0.75-0.96)$ in the flood season, and $0.52(0.39-0.65)$ to $0.58(0.48-0.68)$ in the dry season (Fig. 5), and were positively related to inflow $\left(R^{2}=0.794, \mathrm{P}<0.001\right)$. Allochthony of $P$. tunguidus, $M$. thermocyclopoies and $D$. orghidani varied from a median of $0.32(0.20-0.44)$ to $0.68(0.55-0.81), 0.21(0.06-0.36)$ to

Tab. 1. Summary statistics of multiple regression analysis. Dependent variables: zooplankton biomass, trophic position of $P$. tunguidus and M. thermocyclopoides, zooplankton:phytoplankton biomass ratio, and chlorophyll a:TP ratio. Independent variables: temperature, TP, chlorophyll a, and omnivorous copepod:cladoceran biomass ratio.

\begin{tabular}{|c|c|c|c|c|c|c|}
\hline & $R_{\text {adj }}^{2}$ & $F$-value & $\mathbf{P}$ & Parameter & $t$-value & $\mathbf{P}$ \\
\hline Zooplankton biomass & 0.478 & 7.400 & 0.002 & $\begin{array}{c}\text { TP } \\
\text { Chlorophyll a } \\
\text { Temperature }\end{array}$ & $\begin{array}{l}3.379 \\
0.438 \\
1.444\end{array}$ & $\begin{array}{l}0.003 \\
0.667 \\
0.166\end{array}$ \\
\hline Trophic position of $P$. tunguidus & 0.405 & 4.742 & 0.039 & $\begin{array}{l}\text { Temperature } \\
\text { Chlorophyll a }\end{array}$ & $\begin{array}{c}-0.084 \\
2.901\end{array}$ & $\begin{array}{l}0.935 \\
0.018\end{array}$ \\
\hline Trophic position of $M$. thermocyclopoides & 0.536 & 7.365 & 0.013 & $\begin{array}{l}\text { Temperature } \\
\text { Chlorophyll a }\end{array}$ & $\begin{array}{l}3.345 \\
0.546\end{array}$ & $\begin{array}{l}0.009 \\
0.598\end{array}$ \\
\hline Zooplankton to phytoplankton biomass ratio & 0.320 & 5.930 & 0.010 & $\begin{array}{c}\text { TP } \\
\text { Temperature }\end{array}$ & $\begin{array}{l}2.841 \\
1.562\end{array}$ & $\begin{array}{l}0.011 \\
0.135\end{array}$ \\
\hline Chlorophyll a to TP ratio & 0.843 & 38.470 & $<0.001$ & $\begin{array}{c}\text { Secchi disk depth } \\
\text { Ominvorous copepods to } \\
\text { cladocerans biomass ratio } \\
\text { Temperature }\end{array}$ & $\begin{array}{r}5.659 \\
4.481 \\
-1.705\end{array}$ & $\begin{array}{l}<0.001 \\
<0.001 \\
0.105\end{array}$ \\
\hline
\end{tabular}
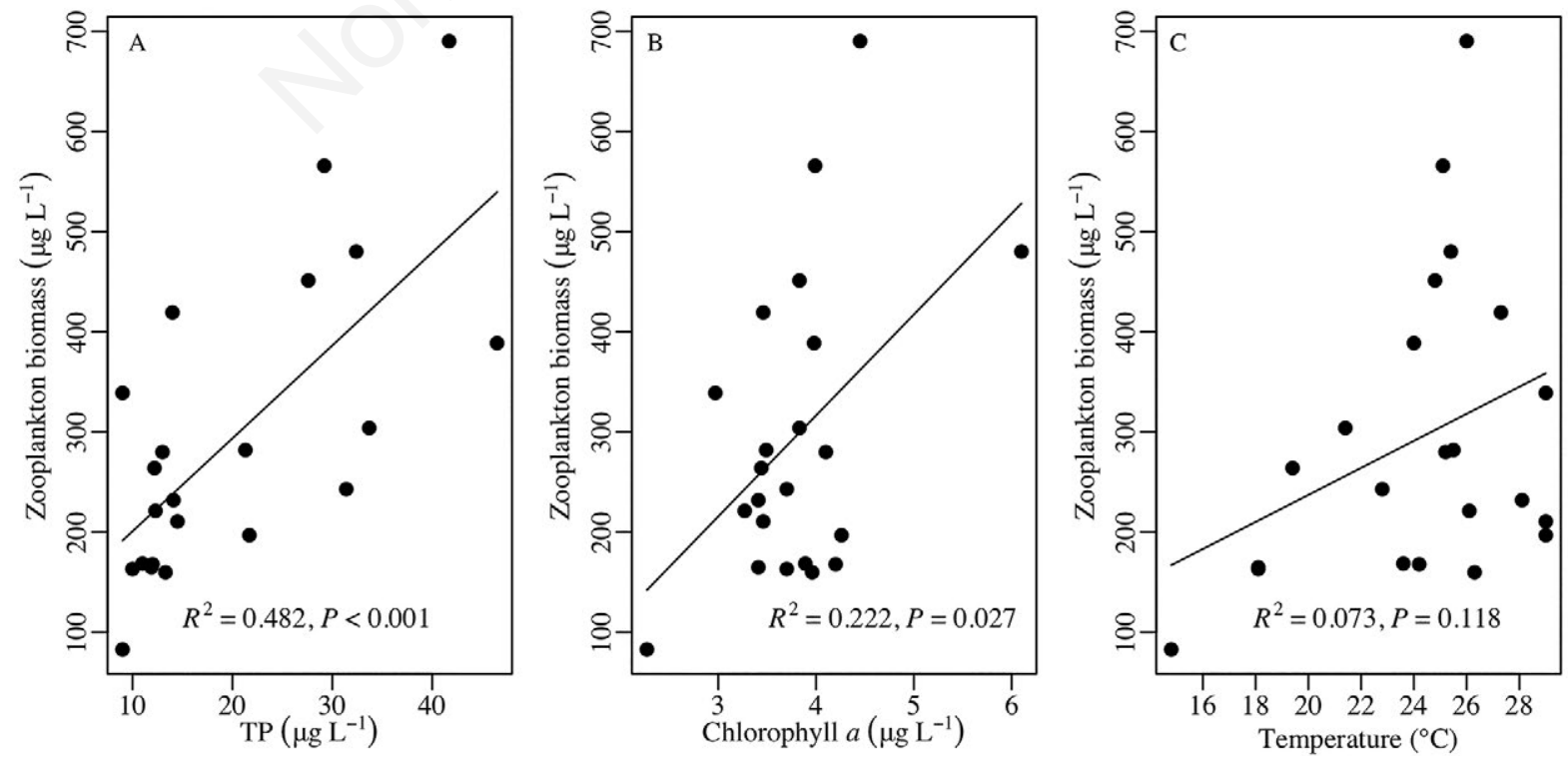

Fig. 3. Zooplankton biomass in relation to (A) TP, (B) chlorophyll a and (C) temperature. 
$0.61(0.46-0.76)$, and $0.28(0.13-0.43)$ to $0.63(0.48-0.78)$, respectively (Fig. 5). The median allochthony values of zooplankton were positively related to the median allochthony values of POM (P. tunguidus: $R^{2}=0.884$, $\mathrm{P}<0.001, M$. thermocyclopoides: $R^{2}=0.788, \mathrm{P}<0.001, D$. orghidani: $\left.R^{2}=0.745, \mathrm{P}<0.001\right)$. The average season-wide median allochthony of $P$. tunguidus (0.61) was relatively higher than that of $M$. thermocyclopoides (0.54) and $D$. orghidani (0.48) in the flood season.

The $\delta^{15} \mathrm{~N}$ value of bulk POM was marginally higher in the dry season than in the flood season (Fig. 4, ANOVA, $\left.F_{1,10}=4.7, \mathrm{P}=0.055\right)$. The three crustaceans showed enrichment by $0.5-10 \%$ in ${ }^{15} \mathrm{~N}$ relative to POM (Fig. 4). The difference between $P$. tunguidus and $D$. orghidani $\delta^{15} \mathrm{~N}$ was $1.0-3.3 \%$. The trophic position of $P$. tunguidus was positively related to chlorophyll a but not to temperature (Fig. 6 A,B; Tab. 1). The difference between $M$. thermocyclopoides and D. orghidani $\delta^{15} \mathrm{~N}$ was $-0.8-3.7 \%$ and changed seasonally. In contrast to $P$. tunguidus, the trophic position of M. thermocyclopoides was positively related to temperature but not to chlorophyll a (Fig. 6 C,D; Tab. 1).

The zooplankton:phytoplankton biomass ratio was significantly higher in the flood season $(0.14 \pm 0.05)$ than in the dry season $(0.09 \pm 0.04)$ (ANOVA, $F_{1,20}=6.6, \mathrm{P}=0.018$ ). Multiple regression showed that the ratio was positively related to TP but not to temperature (Fig. 7, Tab. 1). Nauplii and early copepodites were thought to be herbivorous. The ratio of omnivorous adult copepods to filter-feeding cladoceran biomass varied from 0.18 to 1.88 and was significantly higher in the dry season $(1.06 \pm 0.46)$ than in the flood season $(0.61 \pm 0.36)$ (ANOVA, $F_{1,20}=6.8$, $\mathrm{P}=0.017$ ). The chlorophyll a to TP ratio ranged from 0.09 to 0.37 and was much higher in the dry season $(0.30 \pm 0.04)$ than in the flood season $\left(0.17 \pm 0.07\right.$ ) (ANOVA, $F_{1.20}=25.52$, $\mathrm{P}<0.001)$. This ratio was positively associated with the omnivorous adult copepod:cladoceran biomass ratio and Secchi disk depth, explaining $82.7 \%$ of the variation in the chlorophyll a to TP ratio, but was not associated with temperature (Fig. 8, Tab. 1). The unique effects of the omnivorous adult copepods:cladoceran biomass ratio and Secchi disk depth in variation partitioning were smaller than the joint effect. The unique effect of the omnivorous adult copepods:cladoceran biomass ratio was slightly larger than that of Secchi disk depth.

\section{DISCUSSION}

\section{Seasonal change in terrestrial POM input}

In general, POM of allochthonous sources can be a key portion of nutrient loading in reservoirs (Thornton, 1990). Loadings of terrestrial organic matter to reservoirs can be traced in the $\delta^{13} \mathrm{C}_{\mathrm{POM}}$. The carbon isotopic

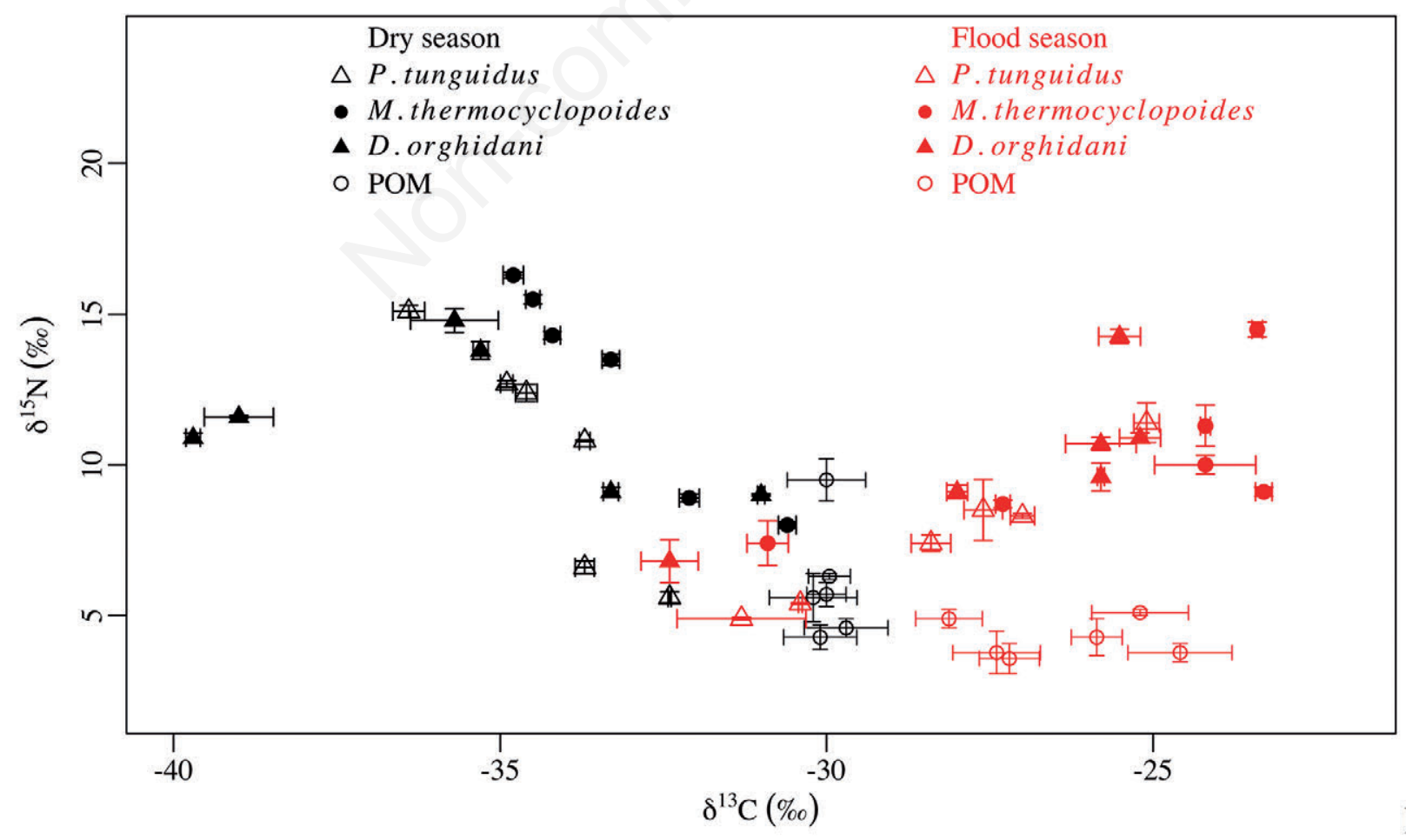

Fig. 4. Seasonal variation in $\delta^{3} \mathrm{C}$ and $\delta^{15} \mathrm{~N}$ of POM, D. orghidani, P. tunguidus and M. thermocyclopoides. Values shown are means \pm SD. 
composition of POM is a function of its carbon sources in phytoplankton, bacteria, and allochthonous and autochthonous detritus. Average $\delta^{13} \mathrm{C}$ of terrestrial $\mathrm{C}_{3}$ and $\mathrm{C}_{4}$ plants is $-27.8 \%$ and $-13.0 \%$, respectively (Peterson and Fry, 1987), and soil organic matter from the floodplains of the Liuxihe Reservoir was slightly enriched in ${ }^{13} \mathrm{C}(-24 \%)$ in comparison with $\mathrm{C}_{3}$ plants, the dominant vegetation in the catchment (Ning, 2013). Consistent with earlier findings (Grey et al., 2001; Karlsson et al., 2003), Ning (2013) found that the $\delta^{13} \mathrm{C}$ value of phytoplankton in Liuxihe Reservoir was lower than that of soil organic carbon, and phospholipid-derived fatty acids of phytoplankton were more ${ }^{13} \mathrm{C}$-enriched in the flood season $\left(-30.5 \%\right.$ ) than in the dry season $\left(-40.1 \%\right.$ ). The $\delta^{13} \mathrm{C}_{\mathrm{POM}}$ value was lower than the $\delta^{13} \mathrm{C}$ value of soil organic matter but higher than that of phytoplankton. Allochthony assessment with a $\delta^{13} \mathrm{C}$ two-source mixing model showed that terrestrial sources contributed more than $50 \%$ to particulate organic C. Particularly high allochthony values of POM and TP concentrations in the early flood season suggest that terrestrial POM loading to the reservoir was higher in the flood season than in the dry season.

\section{Copepods allochthony}

Terrestrial organic carbon often dominates the carbon pools of oligotrophic water bodies and may represent a significant resource for zooplankton consumers (Cole et al., 2006; Jonsson et al., 2007; Kelly et al., 2014). A comparison of zooplankton food sources in small-to-large aquatic systems by Zigah et al. (2012) showed that terrigenous organic carbon was relatively more important in rivers and small lakes and that the proportion of terrestrially derived material used by zooplankton correlated with hydrologic residence time and ratio of basin area to water surface area. Moreover, the proportion of terrestrially derived material used by zooplankton changed seasonally in aquatic systems. In natural lakes, autochthony is often predominant at high within-lake phytoplankton productivity in summer, whereas allochthony is especially important to zooplankton biomass during winter periods when within-lake primary and secondary production is minimal (Grey et al., 2001; Taipale et al., 2008; Karlsson and Sawstrom, 2009; Rautio et al., 2011). Unlike natural lakes, reservoirs generally possess higher basin area to surface area ratio and a shorter hydrologic residence time, and receive large amounts of terrestrial organic matter in the flood season (Straškraba and Tundisi, 1999). Terrestrial input of organic carbon increases the allochthonous resource availability, but they may also reduce the autochthonous resource availability by means of shading effects on phytoplankton (Jones et al., 2012; Kelly et al., 2014). Consequently, in contrast to natural lakes, the allochthony

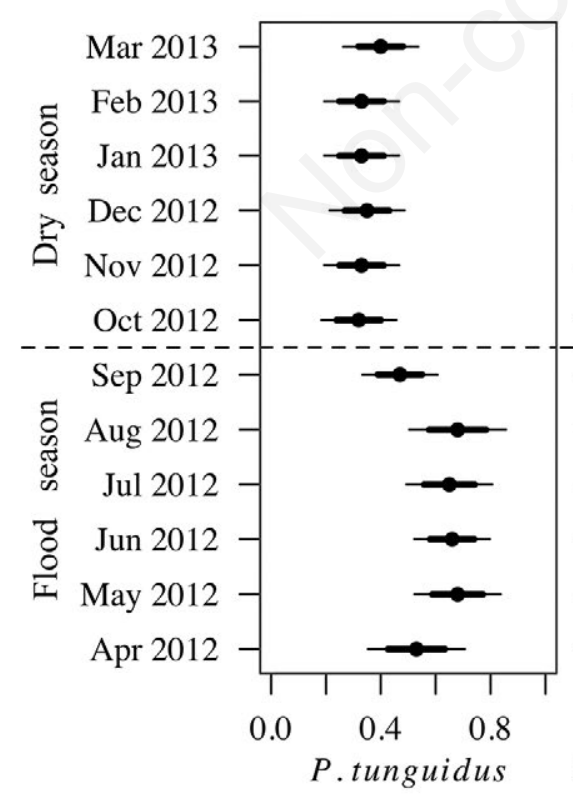

P.tunguidus
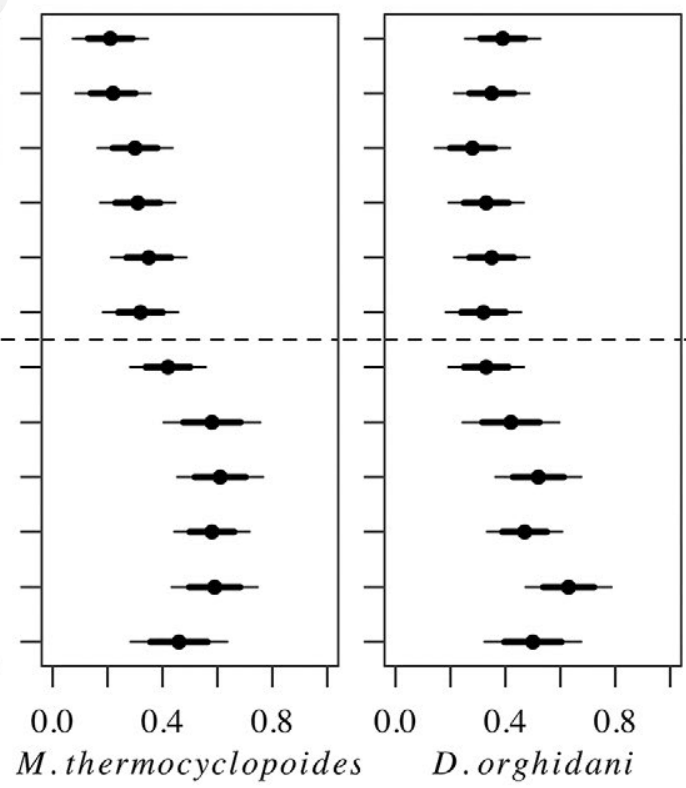

Allochthony

Fig. 5. Median values of allochthony (black dots) and allochthony probability distributions shown for POM, D. orghidani, P. tunguidus and $M$. thermocyclopoides. Thin lines show the $25^{\text {th }}$ and $75^{\text {th }}$ percentiles and thick lines the $5^{\text {th }}$ and $95^{\text {th }}$ percentiles. 
of the three crustacean species in Liuxiher Reservoir was much higher in summer (flood season) than in winter (dry season). Terrestrial sources supplied half of the carbon in zooplankton in the flood season, an amount that is much higher than that found in some temperate lakes (Cole et al., 2006; Zigah et al., 2012; Berggren et al., 2014). Moreover, allochthony of the three crustacean species was correlated with the allochthony of POM, which was positively related to the inflow. Allochthony varies among different zooplankton groups, and copepods are generally thought to be less reliant on terrestrial organic matter than cladocerans (Berggren et al., 2014; Kelly et al., 2014).
However, our results disagree with these reports in that calanoid copepod P. tunguidus in our study relied more on allochthonous carbon than cladoceran $D$. orghidani in the flood season, while no significant difference in allochthony between copepods and cladocerans was found in the dry season.

\section{Copepods as omnivores}

Most copepod species are generally considered to be efficient predators (Brand, 2005), and differences of 2$5 \%$ between copepod and cladoceran $\delta^{15} \mathrm{~N}$ values are
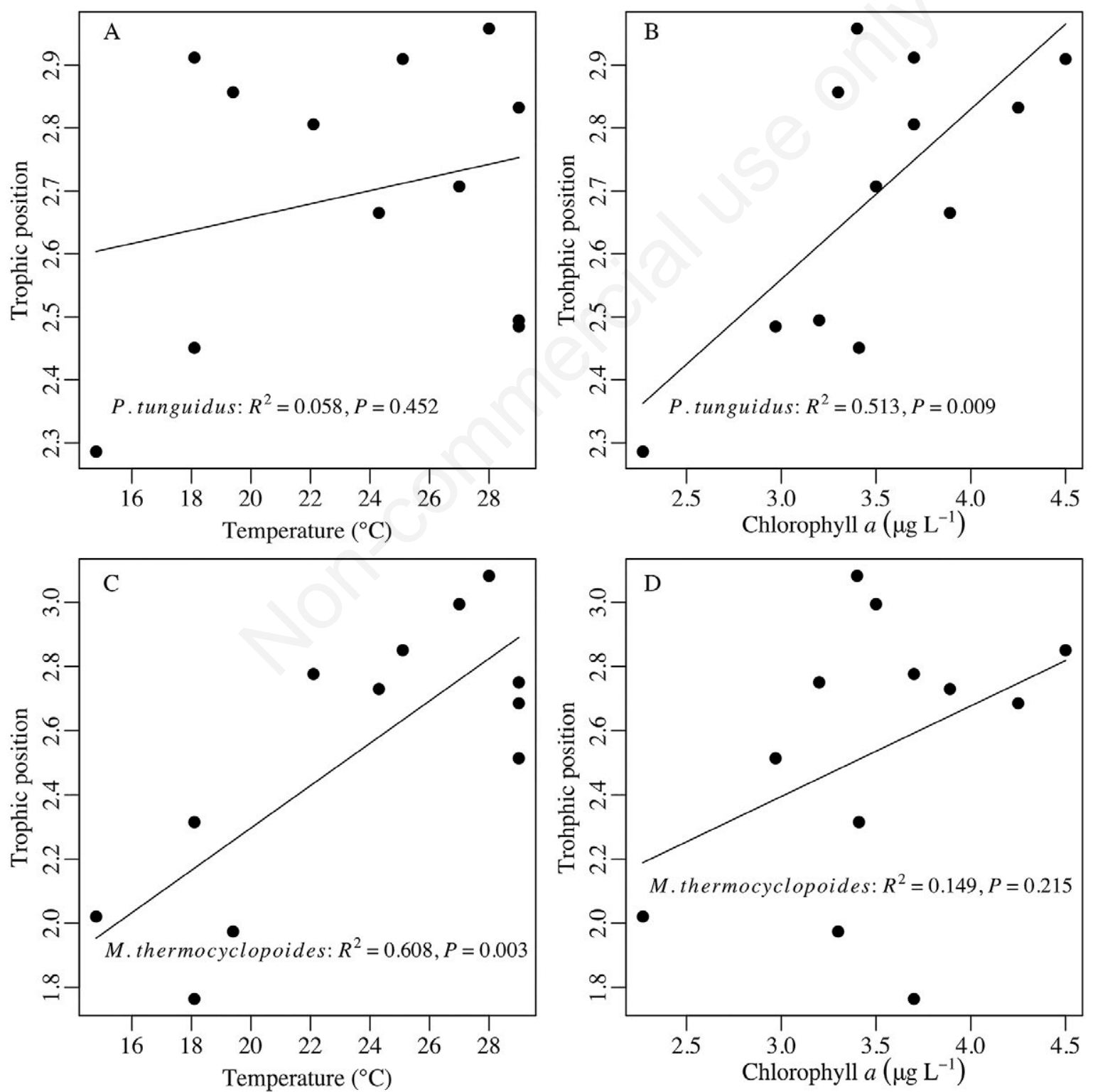

Fig. 6. Trophic positions of adult Phyllodiaptomus tunguidus and Mesocyclops thermocyclopoides versus temperature (A and C) and chlorophyll a (B and D). 
often found (Gu et al., 1994; Meili et al., 1996). Similarly, in the Liuxihe Reservoir, calanoids ( $P$. tunguidus) $\delta^{15} \mathrm{~N}$ values were $1.0-3.3 \%$ higher than those of cladocerans (D. orghidani) throughout the year, and cyclopoids ( $M$. thermocyclopoides) $\delta^{15} \mathrm{~N}$ values were higher by $1.7-3.4 \%$ in the flood season and in the early dry season. Our stable isotope analysis suggests that both copepod species tend to be omnivorous in the reservoir. Omnivores are frequently presumed to feed opportunistically on the most abundant, suitable prey items and may switch prey items as the relative abundance of prey changes (Beatty, 2006). Combining modeling and laboratory experiments, Sentis et al. (2014) suggested that an increase in resource availability decreases the species interaction strength and the occurrence of omnivory, whereas an increase in temperature has the opposite effect. However, several studies in marine systems have shown that some, but not all, copepods change their trophic position depending on the availability of prey and temperature (Landry, 1981; El-Sabaawi et al., 2009; Kürten et al., 2013; Boersma et al., 2016). The extent to which a copepod is a raptorial and carnivorous predator may likely be a species-specific characteristic. In the present study, M. thermocyclopoides showed seasonal differences in trophic position and an increase in trophic position with rising temperatures, whereas $P$. tunguidus remained omnivorous throughout the year. The lack of a significant difference in $\delta^{15} \mathrm{~N}$ values between the two copepod species suggests that they did not differ in trophic position in the flood season. Several studies have shown that copepods prefer protozoans (Kleppel, 1993; Levinsen et al., 2000). It is likely that an increasing terrestrial organic matter input in the flood season would increase the food availability to copepods by fueling the microbial food web, allowing the animals to simultaneously feed in a more carnivorous mode. However, the high ${ }^{15} \mathrm{~N}$-depletion of $M$. thermocyclopoides compared to $P$. tunguidus is an indication that the herbivorous feeding mode played a more important role in the late dry season. Food niche differentiation between the two copepod species suggests that strong interspecific competition in the late dry season, combined with the large trophic position flexibility of $M$. thermocyclopoides, allowed the species to coexist with sympatric competitors.

\section{Trophic cascade from omnivorous copepods to phytoplankton}

Terrestrial input of organic carbon contributes to basal resource availability in lakes, but may also reduce resource availability by way of shading effect on phytoplankton (Jones et al., 2012). The positive relationship between the chlorophyll a:TP ratio and Secchi disk depth suggests that there was a shading effect of terrestrial organic matter on primary production, particularly in the early flood season. Total phosphorus concentration in the early flood season was much higher than at other times of the year, but Secchi disk depth and the chlorophyll a:TP ratio was much lower. Pronounced allochthony of copepods suggests that zooplankton production was not only sustained by primary production but also by terrestrial organic matter. Therefore increases
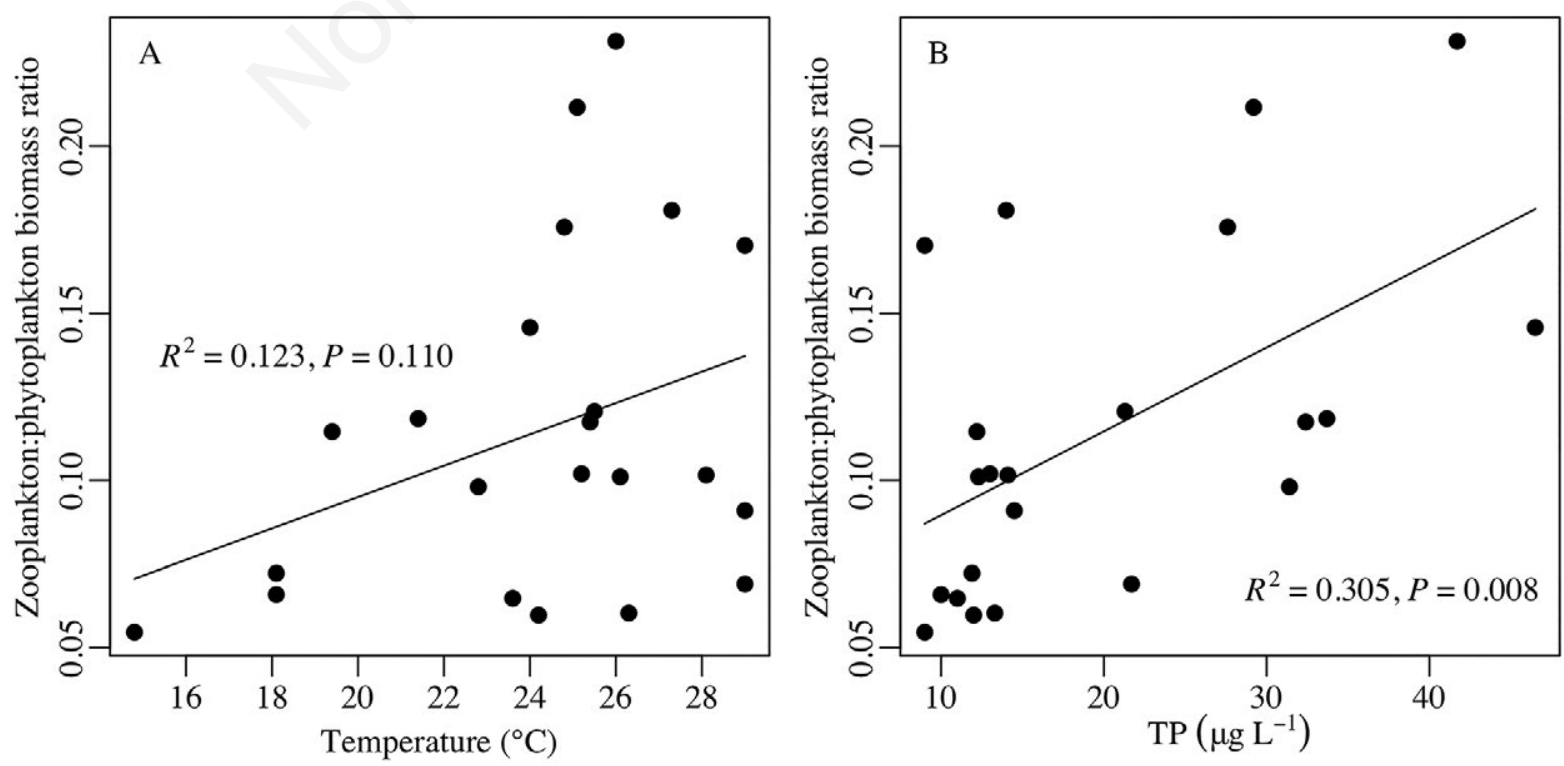

Fig. 7. Zooplankton:phytoplankton biomass ratio in relation to (A) temperature and (B) TP. 
in terrestrial organic matter tend to stimulate zooplankton reproduction and population growth either directly or through fueling the microbial food web. This led to increased zooplankton biomass with TP. Similar to that found in north temperate oligotrophic to mesotrophic lakes (Jeppesen et al., 2010), increased zooplankton biomass with TP in Liuxihe Reservoir enhanced the biomass ratio of zooplankton to phytoplankton. In north temperate lakes, large crustacean grazers (Daphnia) dominate the zooplankton community. Increased
Daphnia grazing pressure would cascade down the food web, resulting in a higher zooplankton to phytoplankton biomass ratio and a lower chlorophyll a to TP ratio (Jeppesen et al., 2010). In contrast, the zooplankton in Liuxihe Reservoir was dominated by omnivorous copepods most of the time, and a higher zooplankton to phytoplankton biomass ratio did not necessarily lead to a lower chlorophyll a to TP ratio. In a laboratory food chain experiment with the copepod Acartia tonsa as top predator, Siuda and Dam (2010) found that a decrease in
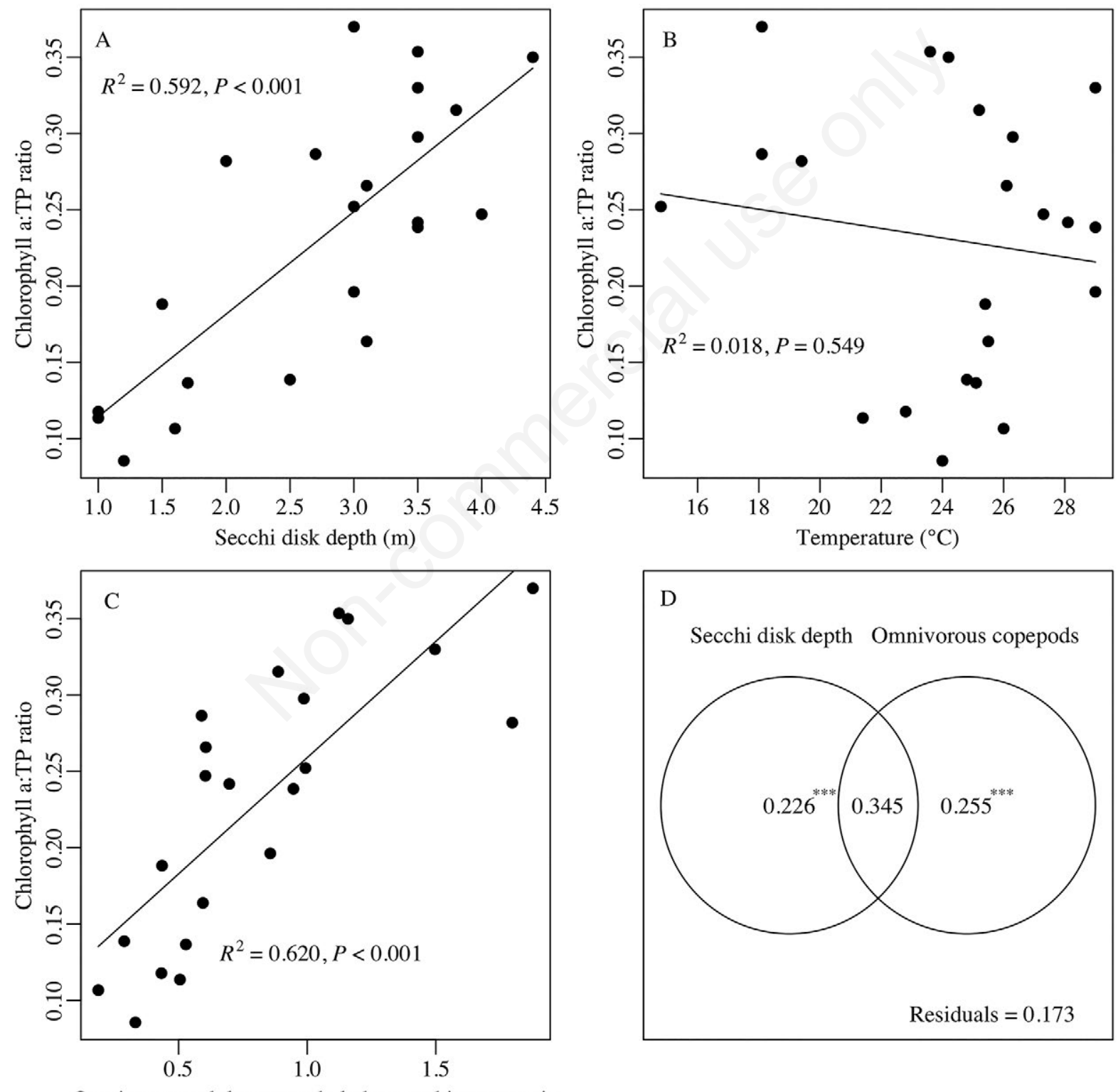

Omnivorous adult copepod:cladoceran biomass ratio

Fig. 8. Chlorophyll a:TP ratio in relation to (A) Secchi disk depth, (B) temperature and (C) omnivorous adult copepod:cladoceran biomass ratio, and (D) Venn diagram of the variation partitioning of the chlorophyll a:TP ratio explained by Secchi disk depth and the omnivorous adult copepod:cladoceran biomass ratio. 
phytoplankton due to direct grazing by $A$. tonsa was much greater than any indirect increase resulting from reduced microzooplankton grazing pressure. They argued that omnivory would weaken the indirect cascading effects of the top predator on the phytoplankton, and that omnivorous copepods exert a negative cascading effect on phytoplankton. However, in our study, the chlorophyll a:TP ratio increased with the increasing omnivorous adult copepod:cladoceran biomass ratio, suggesting copepods produced an indirect positive effect on the phytoplankton biomass. Copepods may have a negative effect on large phytoplankton through direct grazing but a positive effect on small phytoplankton by reducing microzooplankton grazing pressure. The effect of copepods on total phytoplankton biomass will depend on copepods' preference for microzooplankton as opposed to large phytoplankton and on the relative initial abundances of large and small phytoplankton. If the indirect cascading effect on small phytoplankton was stronger than the direct grazing effect on large phytoplankton, copepods would have a positive effect on the total phytoplankton biomass that will lead to a higher chlorophyll a:TP ratio. As Liuxihe Reservoir is an oligo-mesotrophic water body, the phytoplankton is primarily dominated by small species, of which most tolerate nutrient deficiency (Xiao et al., 2011). Xiao and colleagues (2011) argued that light and phosphorus availability were the primary factors inducing seasonal change in phytoplankton community structure and biomass change. In our study, phytoplankton $>30 \mu \mathrm{m}$ (Peridinium and Ceratium hirundinella) generally contributed less than $10 \%$ of total phytoplankton biomass irrespective of TP (Fig. 2), while phytoplankton $<30 \mu \mathrm{m}$ increased with TP. Moreover, the chlorophyll a:TP ratio increased with an increasing omnivorous adult copepod:cladoceran biomass ratio. Cyclotella dominated the small phytoplankton in MayJune and December-January, while Peridiniopsis dominated for the remainder of the year (Fig. 2). Therefore, it is likely that large phytoplankton species were outcompeted by small phytoplankton species and that the competitive pressure was stronger than the grazing effect of adult copepods on large phytoplankton. As large phytoplankton maintained an extremely low abundance irrespective of the composition of zooplankton and TP, a likely explanation for a higher chlorophyll a to TP ratio when copepods dominated the zooplankton is that the indirect cascading effect of copepods on small phytoplankton was stronger than direct grazing effect on large phytoplankton. Meanwhile, terrestrial organic phosphorus is generally unavailable to phytoplankton but can be incorporated into the microzooplankton biomass via the microbial loop. Furthermore, copepods may favor small phytoplankton by recycling terrestrial organic phosphorus by feeding on microzooplankton.

\section{CONCLUSIONS}

Our data indicate that both calanoids and cyclopoids tend to be omnivorous in tropical reservoirs of China where the zooplankton communities are generally dominated by copepods. The input of terrestrial organic matter may stimulate copepod population growth but may also have a shading effect on the phytoplankton. Preference for microzooplankton may favor small phytoplankton by reducing the grazing pressure on small phytoplankton and enhancing nutrient recycling. Both allochthony and omnivory in copepods are likely to have a positive total effect on the phytoplankton.

\section{ACKNOWLEDGMENTS}

We are grateful to Dr. Ken Chen, Australia, and Anne Mette Poulsen, Denmark, for reading and commenting on the manuscript. We thank all students at the field station for their help with sampling and sample counting. We also thank two anonymous reviewers for their constructive criticisms. This work was funded by the National Natural Science Foundation of China (grant no. 41573062) and the Science and Technology Project of Guangdong Province (grant no. 2015B020235007).

\section{REFERENCES}

Beatty SJ, 2006. The diet and trophic positions of translocated, sympatric populations of Cherax destructor and Cherax cainii in the Hutt River, Western Australia: evidence of resource overlap. Mar. Freshwater Res. 57:825-35.

Berggren M, Ziegler SE, St-Gelais NF, Beisner BE, del Giorgio PA, 2014. Contrasting patterns of allochthony among three major groups of crustacean zooplankton in boreal and temperate lakes. Ecology 95:1947-1959.

Boersma M, Mathew KA, Niehoff B, Schoo KL, Franco-Santos RM, Meunier CL, 2016. Temperature driven changes in the diet preference of omnivorous copepods: no more meat when it's hot? Ecol. Lett. 19:45-53.

Brand Z, 2005. Freshwater copepods and rotifers: predators and their prey. Hydrobiologia 546:475-489.

Carpenter SR, Cole JJ, Pace ML, Van de Bogert M, Bade DL, Bastviken D, Gille CM, Hodgson JR, Kitchell JF, Kritzberg ES, 2005. Ecosystem subsidies: terrestrial support of aquatic food webs from ${ }^{13} \mathrm{C}$ addition to contrasting lakes. Ecology $86: 2737-2750$

Chen F, Jia G, 2009. Spatial and seasonal variations in $\delta^{13} \mathrm{C}$ and $\delta^{15} \mathrm{~N}$ of particulate organic matter in a dam-controlled subtropical river. River. Res. Applic. 25:1169-1176.

Cole JJ, Carpenter SR, Pace ML, Van de Bogert MC, Kitchell JL, Hodgson JR, 2006. Differential support of lake food webs by three types of terrestrial organic carbon. Ecol. Lett. 9:558-568.

Cole JJ, Carpenter SR, Kitchell J, Pace ML, Solomon CT, Weidel B, 2011. Strong evidence for terrestrial support of 
zooplankton in small lakes based on stable isotopes of carbon, nitrogen, and hydrogen. P. Natl. Acad. Sci USA 108:1975-1980.

Comerma M, García JC, Romero M, Armengol J, Šimek K, 2003. Carbon flow dynamics in the pelagic community of the Sau Reservoir (Catalonia, NE Spain). Hydrobiologia 504:87-98

Conley WJ, Turner JT, 1985. Omnivore by the coastal marine copepods Centropages hamaztus and Labidocera aestiva. Mar. Ecol. Prog. Ser. 21:113-120.

DeMott WR, 1988. Discrimination between algae and artificial particles by freshwater and marine copepods. Limnol. Oceanogr. 33:397-408.

El-Sabaawi R, Dower JF, Kainz M, Mazumder A, 2009. Characterizing dietary variability and trophic positions of coastal calanoid copepods: insight from stable isotopes and fatty acids. Mar. Biol. 156:225-237.

Feuchtmayr H, Zöllner E, Santer B, Sommer U, Grey J, 2004. Zooplankton interactions in enclosure experiment: insights from stable isotope analyses. Freshwater Biol. 49:1495-1504.

Filstrup CT, Wagner T, Soranno PA, Stanley EH, Stow CA, Webster KE, Downing JA, 2014. Regional variability among nonlinear chlorophyll-phosphorus relationships in lakes. Limnol. Oceanogr. 59:1691-1703.

Francis TB, Schindler DE, Holtgrieve GW, Larson ER, Scheuerell MD, Semmens BX, Ward EJ, 2011. Habitat structure determines resource use by zooplankton in temperate lakes. Ecol. Lett. 14:364-372.

Gelman A, Su Y-S, Yajima M, Hill J, Pittau MG, Kerman J, Zheng T, Dorie V, 2016. Arm: Data analysis using regression and multilevel/hierarchical models. Available from: http://CRAN.R-project.org/package=arm

Grey J, Jones RI, Sleep D, 2001. Seasonal changes in the importance of the source of organic matter to the diet of zooplankton in Loch Ness, as indicated by stable isotope analysis. Limnol. Oceanogr. 46:505-513.

Gu B, Schell DM, Alexander V, 1994. Stable carbon and nitrogen isotopic analysis of the plankton food web in a subarctic lake. Can. J. Fish. Aquat. Sci. 51:1338-1344.

Harris D, Horwath WR, van Kessel C, 2001. Acid fumigation of soils to remove carbonates prior to total organic carbon or carbon-13 isotopic analysis. Soil Sci. Soc. Am. J. 65:1853-1856.

Ivatin AV, 1974. Production of phytoplankton and decomposition of organic matter in the Kuybyshev reservoir. Hydrobiologia 10:49-52.

Jeppesen E, Lauridsen TL, Kairesalo T, Perrow M, 1997. Impact of submerged macrophytes on fish-zooplankton relationships in lakes, p. 91-115. In: E. Jeppesen, M. Søndergaard and K. Christoffersen (eds.), The structuring role of submerged macrophytes in lakes. Ecological studies. Springer Verlag, New York.

Jeppesen E, Meerhoff M, Holmgren K, González-Bergonzoni I, Teixeira-de Mello F, Declerck SAJ, De Meester L, Søndergaard M, Lauridsen TL, Bjerring R, Conde-Porcuna JM, Mazzeo N, Iglesias C, Reizenstein M, Malmquist H, Liu Z, Balayla D, Lazzaro X, 2010. Impacts of climate warming on lake fish community structure and potential effects on ecosystem function. Hydrobiologia 646:73-90.

Jones RI, Grey J, Sleep D, Quarmby C, 1998. An assessment, using stable isotopes, of the importance of allochthonous organic carbon sources to the pelagic food web in Loch Ness. P. Roy. Soc. B-Biol Sci 265:105-111.

Jones SE, Solomon CT, Weidel BC, 2012. Subsidy or subtraction: how do terrestrial inputs influence consumer production in lakes? Freshwater Rev. 5:37-49.

Jonsson A, Algesten G, Bergström AK, Bishop K, Sobek S, Tranvik LJ, Jansson M, 2007. Integrating aquatic carbon fluxes in a boreal catchment carbon budget. J. Hydrol. 334:141-150.

Karlsson J, Berggren M, Ask J, Byström P, Jonsson A, Laudon H, Jansson M, 2012. Terrestrial organic matter support of lake food webs: Evidence from lake metabolism and stable hydrogen isotopes of consumers. Limnol. Oceanogr. 57:1042-1048.

Karlsson J, Jonsson A, Meili M, Jansson M, 2003. Control of zooplankton dependence on allochthonous organic carbon in humic and clear-water lakes in northern Sweden. Limnol. Oceanogr. 48:269-276.

Karlsson J, Säwström C, 2009. Benthic algae support zooplankton growth during winter in a clear-water lake. Oikos 118:539-544.

Kelly PT, Solomon CT, Weidel BC, Jones SE, 2014. Terrestrial carbon is a resource, but not a subsidy, for lake zooplankton. Ecology 95:1236-1242.

Kleppel GS, 1993. On the diet of calanoid copepods. Mar. Ecol. Prog. Ser. 99:183-195.

Korovchinsky NM, 1992. Sididae \& Holopediidae (Crustacea: Daphniiformes). SPB Academic Publishing, The Hague: 82 pp.

Koste W, 1978. [Rotatoria. Die Rädertiere Mitteleuropas].[Book in German]. Gebrüder Borntraeger, Berlin: 276 pp.

Kürten B, Painting SJ, Struck U, Polunin NVC, Middleburg JJ, 2013. Tracking seasonal changes in North Sea zooplankton trophic dynamics using stable isotopes. Biogeochemistry 113:167-187.

Landry MR, 1981. Switching between herbivory and carnivory by the planktonic marine copepod Calanus pacificus. Mar. Biol. 65:77-82.

Levinsen H, Turner JT, Nielsen TG, Hansen BW, 2000. On the trophic coupling between protists and copepods in arctic marine ecosystems. Mar. Ecol. Prog. Ser. 204:65-77.

Lin S-J, He L-J, Huang P-S, Han B-P, 2005. Comparison and improvement on the extraction method for chlorophyll a in phytoplankton. Ecol. Sci. 24:9-11.

Lin Q, Han B-P, Dumont HJ, 2012. Seasonal dynamics of Daphnia galeata in a reservoir at the edge of the tropics before and after yearly stocking with bighead carp, p. 4358. In: B-. Han and Z. Liu (eds.), Tropical and sub-tropical reservoir limnology in China. Springer, Dordrecht.

Lin Q, Jiang X, Han B-P, Jeppesen E, 2014. Does stocking of filter-feeding fish for production have a cascading effect on zooplankton and ecological state? A study of fourteen (sub)tropical Chinese reservoirs with contrasting nutrient concentrations. Hydrobiologia 736:115-125.

Lin Q, Zhao S, Han B, 2006. Spatial and temporal variation of metazooplankton biomass size spectrum in Liuxihe Reservoir, Guangdong Province. J. Lake Sci. 18:661-669.

Matthews B, Mazumder A, 2003. Compositional and interlake variability of zooplankton affect baseline stable isotope signatures. Limnol. Oceanogr. 48:1977-1987. 
Mazumder A, 1994. Phosphorus-chlorophyll relationships under contrasting zooplankton community structure: potential mechanisms. Can. J. Fish. Aquat. Sci. 51:401-407.

McCutchan JH, Lewis WM, Kendall C, McGrath CC, 2003. Variation in trophic shift for stable isotopes ratios of carbon, nitrogen, and sulfur. Oikos 102:378-390.

Meili M, Kling GW, Fry B, Bell RT, Ahlgren I, 1996. Sources and partitioning of organic matter in a pelagic microbial food web inferred from the isotopic composition $\left(\delta^{13} \mathrm{C}\right.$ and $\delta^{15} \mathrm{~N}$ ) of zooplankton species. Arch. Hydobiol. Spec. Issues Advanc. Limnol. 48:53-61.

Murphy J, Riley JP, 1962. A modified single solution method for the determination of phosphate in natural waters. Anal. Chim. Acta 27:31-36.

Ning J, 2013. The study on organic carbon sources supporting food webs in Liuxihe reservoir and Dashahe reservoir. PhD Thesis, Jinan University, Guangzhou, China. Available from: http://thesis.jnu.edu.cn/search/article?id=19259

Ning J, Liu H, Gu B, Liu Z, 2012. Carbon and nitrogen stable isotope characteristics of particulate organic matter and zooplankton in Liuxihe Reservoir. Acta Ecol. Sin. 32:15021509.

Oksanen J, Blanchet FG, Friendly M, 2017. Vegan: Community Ecology Package. Available from: http://github.com/ vegandevs/vegan.

Parnell A, Inger R, 2016. Package 'simmr'. Available from: https://cran.r-project.org/web/packages/simmr/simmr.pdf

Peterson BJ, Fry B, 1987. Stable isotopes in ecosystem studies. Ann. Rev. Ecol. Syst. 18:293-320.

Post DM, 2002. Using stable isotopes to estimate trophic position: models, methods, and assumptions. Ecology 83:703-718.

Rautio M, Mariash H, Forsström L, 2011. Seasonal shifts between autochthonous and allochthonous carbon contribution to zooplankton diets in a subarctic lake. Limnol. Oceanogr. 56:1513-1524.

R Development Core Team, 2015. R: a language and environment for statistical computing, Ver. 3.2.2. R Foundation for Statistical Computing, Vienna, Austria.

Sarnelle O, 1992. Nutrient enrichment and grazer effects on phytoplankton in lakes. Ecology 73:551-560.

Sentis A, Hemptinne J-L, Brodeur J, 2014. Towards a mechanistic understanding of temperature and enrichment effects on species interaction strength, omnivory and foodweb structure. Ecol. Lett. 17:785-793.

Shen CJ, Song DX, 1979. Calanoida. In: C.J. Shen (ed.), Freshwater copepoda. Science Press, Beijing.

Šimek K, Armengol J, Comerma M, Garcia JC, Kopeck P, Nedoma J, Hejzlar J, 2001. Changes in the epilimnetic bacterial community composition, production, and protistinduced mortality along the longitudinal axis of a highly eutrophic reservoir. Microb. Ecol. 42:359-371.

Siuda ANS, Dam HG, 2010. Effects of omnivory and predator- prey elemental stoichiometry on planktonic trophic interactions. Limnol. Oceanogr. 55:2107-2116.

Stibor H, Vadstein O, Diehl S, Gelzleichter A, Hansen T, Hantzsche F, Katechakis A, Lippert B, Løseth K, Peters C, Roederer W, Sandow M, Sundt-Hansen L, Olsen Y, 2004. Copepods act as a switch between alternative marine trophic cascades in pelagic food webs. Ecol. Lett. 7:321-328.

Straškraba M, Tundisi JG, 1999. Guidelines of lake management: Reservoir water quality management. International Lake Environment Committee Foundation, Shiga.

Sommer U, Sommer F, 2006. Cladocerans versus copepods: the cause of contrasting top-down controls on freshwater and marine phytoplankton. Oecologia 147: 83-194.

Sommer U, Sommer F, Santer B, Jamieson C, Boersma M, Becker C, Hansen T, 2001. Complementary impact of copepods and cladocerans on phytoplankton. Ecol. Lett. 4:545-550.

Spears BM, Carvalho L, Dudley B, May L, 2013. Variation in chlorophyll a to total phosphorus ratio across 94 UK and Irish lakes: Implications for lake management. J. Environ. Manage. 115:287-294.

Taipale S, Kankaala P, Tiirola M, Jones RI, 2008. Whole-Lake dissolved inorganic ${ }^{13} \mathrm{C}$ additions reveal seasonal shifts in zooplankton diet. Ecology 89:463-474.

Thornton KW, 1990. Perspectives on reservoir limnology, p. 113. In: K.W. Thornton, B.L. Kimmel and F.E. Payne (eds.), Reservoir limnology: Ecological perspectives. J. Wiley \& Sons, New York.

Ueda H, Reid JW, 2003. Copepoda: Cyclopoida genera Mesocyclops and Thermocyclops. Backhuys Publishers, Leiden: $318 \mathrm{pp}$.

Vanni MJ, Findlay DL, 1990. Trophic cascades and phytoplankton community structure. Ecology 71: 921-937.

Wang S, Qian X, Han B-P, Wang Q-H, Ding Z-F, 2011. Physical limnology of a typical subtropical reservoir in south China. Lake and Reserv. Manag. 27:149-161.

Wang S, Qian X, Wang Q-H, Xiong W, 2012. Modeling turbidity intrusion processes in flooding season of a canyon-shaped reservoir, South China. Procedia Environ. Sci. 13:13271337.

Wilkinson GM, Carpenter SR, Cole JJ, Pace ML, 2014. Use of deep autochthonous resources by zooplankton: Results of a metalimnetic addition of ${ }^{13} \mathrm{C}$ to a small lake. Limnol. Oceanogr. 59:986-996.

Xiao L-J, Wang T, Hu R, Han B-P, Wang S, Qian X, Padisák J, 2011. Succession of phytoplankton functional groups regulated by monsoonal hydrology in a large canyon-shaped reservoir. Water Res. 45:5099-5109.

Zigah PK, Minor EC, Werne JP, Leigh McCallister S, 2012. An isotopic $\left(\Delta^{14} \mathrm{C}, \delta^{13} \mathrm{C}\right.$, and $\left.\delta^{15} \mathrm{~N}\right)$ investigation of the composition of particulate organic matter and zooplankton food sources in Lake Superior and across a size-gradient of aquatic systems. Biogeosciences 9:3663-3678. 